\title{
Ozone generation process using parallel plates plasma reactor at room temperature
}

\author{
Sheila Nadhifa ${ }^{1}$, Renno Afriansyah ${ }^{1}$, and Setijo Bismo ${ }^{1, *}$ \\ ${ }^{1}$ Faculty of Engineering, Department of Chemical Engineering, Universitas Indonesia, Depok 16424, Indonesia
}

\begin{abstract}
Ozone is one of the most powerful oxidizing equipment, so it is effectively used to kill bacteria, viruses, and fungi. Many industrial processes use ozone because ozone can run without forming a byproduct in water. Nevertheless, the utilization of ozone in Indonesia has not been applied maximally, due to the large cost of commercial ozonator equipment and operational life that is relatively short. In addition, many still do not comprehensively comprehend the ozonation process that is relatively very fast in the presence of ozone conditions that can only last a few minutes before parsing back into oxygen. In this study, the DBD (Dielectric Barrier Discharge) plasma reactor model with parallel plates for ozone generation at room temperature was developed. Furthermore, this study is more focused on conducting performance tests and optimizing ozone productivity in parallel spacer corona discharge chambers. This designated ozonator was treated as a plasma reactor to perform various tests with varying feed flow rates, input voltages, and gas feeds (compressed air and medical oxygen). After the productivity of the ozonators were tested with iodometric titration method, the ozonator's productivity in generating ozone and its optimum operating condition were obtained. It can produce up to $0.82 \mathrm{~g}$ ozone $/ \mathrm{h}$ with compressed air feed and $6.45 \mathrm{~g}$ ozone $/ \mathrm{h}$ with medical oxygen feed.
\end{abstract}

\section{Introduction}

As a powerful oxidizing agent, ozone is very effectively used to kill bacteria, viruses and fungi in various pharmaceutical industries. In addition, ozone can disable and even kill some of the microorganisms that are difficult to disinfect [1-2]. Aside from being a disinfectant, ozone is also effective for the decomposition and / or removal of harmful organic compounds, such as phenol, atrazine, dioxin, and so on. Because ozone can be used and operated without forming a by-product in water, many chemical and manufacturing industries use ozone. This can be effectively exploited because unreacted ozone gas can be turned back into oxygen, which is then dissolved or aerated in water.

Common methods used for ozone production are the corona discharge method, electrochemical methods, and ultraviolet radiation methods [3-4]. In this case, the method with the highest ozone productivity is the corona discharge method, which makes it the most widely used ozonator device on the market or as a commercial product. Since the corona discharge method has the highest ozone productivity, it is used for this research with dielectric barrier discharges.

The construction of the current evolving electrical ozone generator is the result of the evolution of Werner von Siemens's design in 1857. [4] Siemens developed a coaxial electric discharge ozonator, which is the beginning for most of today's ozone generators.
Although the are many benefits of ozone, the utilization in Indonesia has not been maximally applied, due to the large cost of commercial ozonators and short or damaged usage life, especially ozone can last only a few minutes before decomposing into oxygen again. It was expected that this research would be able to obtain new type of ozonator which is easy and cheap in terms of manufacture and maintenance and has high productivity.

Several studies had been developed within the Department of Chemical Engineering in Universitas Indonesia to obtain ozonator with economical cost and optimal ozone production. In 2009, Adi Lukmanto, made a shell and tube ozonator consisting of five series of parallel coaxial electrode pipes. From the results of the ozone production test, it was obtained the highest ozone production of $0.4 \mathrm{~g} / \mathrm{h}$ using air feed [8]. In 2011, Aryani Adami, made an ozonator with five corona discharge chambers. It was obtained the highest ozone production of of $0.3 \mathrm{~g} / \mathrm{h}$ using air feed. [9]

In this research, the configuration of plasma reactor with parallel plates model was designed and developed. While it can convert many type of gas, the plasma reactor was used and studied as an ozonator. The superiority assumption of the parallel plates compared with the previous ozonators in coaxial form is in their geometry [10]. With parallel shapes, the surface area of contact or plasma discharge was assumed to be larger than the coaxial form with the same plates size.

Furthermore, the performance test and optimization for the productivity of the parallel plates plasma reactor

\footnotetext{
* Corresponding author: setijo.bismo@ui.ac.id
} 
were analyzed. Then the productivity data of the parallel plates plasma reactor in producing ozone was obtained, which was expected to exceed the previous models.

\section{Material and methods}

The parallel plates plasma reactor was designed and developed by modifying a car ozonizer device which has two electrodes arranged in parallel configuration (Dielectric Barrier Discharge). Modification was done by installing acrylic that acts as shell so the contact that occurs between the gas feed and the electrodes is optimum. The acrylic plates were attached with screws and epoxy adhesives, then silicone glue were used to prevent gas leakage. The reactor scheme can be seen in Figure 1 below.

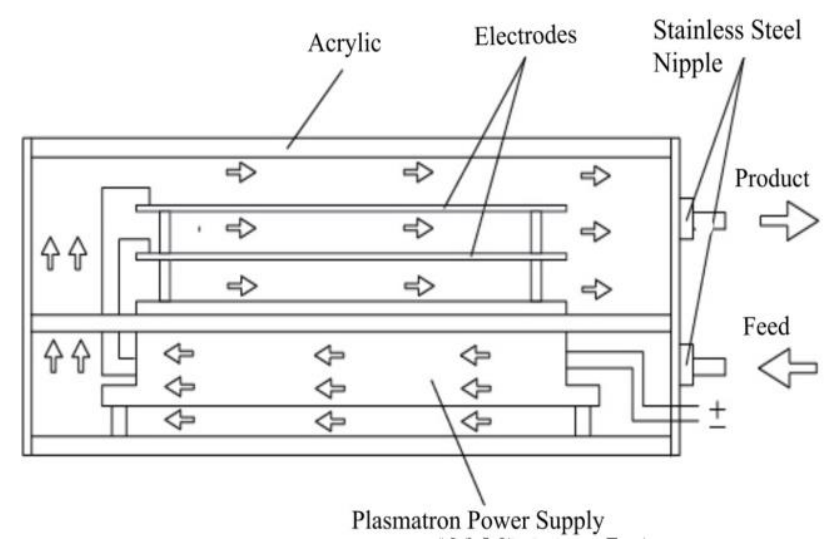

Fig. 1. The schematic of parallel plates plasma reactor

The input voltage source used for the reactor was obtained directly from the PLN which then can be regulated by using diode bridge for DC current and a dimmer switch for AC current. The gas feed was regulated with flowmeter and transferred by hose from a compressor and medical oxygen tube. Iodometric method was used for the calculation of ozone produced per hour. Iodometric titration is a method of volumetric chemical analysis, a redox titration where the appearance or disappearance of elementary iodine indicates the end point.

\section{1 lodometric method}

The working principle of this method is based on the reactivity of ozone to potassium iodide solution, using sulfuric acid solution, starch indicator, and sodium thiosulfate. Then the volume of sodium thiosulfate $\left(\mathrm{Na}_{2} \mathrm{~S}_{2} \mathrm{O}_{3} .5 \mathrm{H}_{2} \mathrm{O}\right)$ in the upstream and downstream ozone bubbler for the titration are used to calculate the amount of ozone produced per hour [6-7]. This study is conducted by varying the input voltage, feed flow rate, and the type of feed gas.

The contact between KI solution and ozone results oxidation reaction that causes color changes to the solution from clear to brownish yellow. The color indicates the forming of $\mathrm{I}_{2}$ from the $\mathrm{I}^{-}$oxidation reaction as follows:

$$
\mathrm{O}_{3}+2 \mathrm{I}^{-}+\mathrm{H}_{2} \mathrm{O} \rightarrow \mathrm{I}_{2}+2 \mathrm{OH}^{-}+\mathrm{O}_{2}
$$

From the equation above it can be seen that the mole of $\mathrm{I}_{2}$ formed is proportional to the mole of ozone required to oxidize KI, so that the mole of $\mathrm{I}_{2}$ can be used to calculate the mole of ozone produced by the ozonator of the design. The method of determining the number of moles of $\mathrm{I}_{2}$ formed is by titrating the solution with sodium thiosulfate as in reaction (2), after first adding sulfuric acid and starch indicator. The function of sulfuric acid is to minimize $I_{2}$ released into the air. The complete reaction of the titration is as reaction (3) belowing.

$$
\begin{aligned}
& \mathrm{I}_{2}+2 \mathrm{Na}_{2} \mathrm{~S}_{2} \mathrm{O}_{3} \rightarrow 2 \mathrm{NaI}+\mathrm{Na}_{2} \mathrm{~S}_{4} \mathrm{O}_{6} \\
& \mathrm{O}_{3}+\mathrm{H}_{2} \mathrm{O}+2 \mathrm{Na}_{2} \mathrm{~S}_{2} \mathrm{O}_{3} \rightarrow 2 \mathrm{OH}^{-}+4 \mathrm{Na}^{+}+\mathrm{S}_{4} \mathrm{O}_{6}^{2-}+\mathrm{O}_{2}
\end{aligned}
$$

From the equation above, it is obtained a relationship, that 1 mole of $\mathrm{O}_{3} \approx 2$ moles of $\mathrm{Na}_{2} \mathrm{~S}_{2} \mathrm{O}_{3}$. Titrations are performed until the amount of $\mathrm{I}_{2}$ is proportionally stoichiometric with sodium thiosulfate, which is indicated by the color of the clear solution. From the two equations of the above reaction, the amount of mole of ozone formed by the ozonator is equal to half the number of moles of sodium thiosulfate used for the titration, and the ozonator productivity can be calculated by dividing the mole of ozone with the time required to change the color of the KI solution in the downstream into a light yellow, the amount of ozone produced from the ozonator.

\section{Result and discussion}

All research results related to this paper are presented in the paragraphs below.

\subsection{Leak and start-up reactor test}

Before testing the performance of the plasma reactor, start-up test must be done to determine the minimum and maximum voltage where the ozone began to form. The start-up test was carried out by turning on the reactor and flowing compressed air feed to start the ozone generation.

\subsection{The effect of compressed air flow rate on ozone production}

In this experiment to study the effect of varying the gas feed flow rate on ozone production, three variations of compressed air flow rates (i.e. $300 \mathrm{~L} / \mathrm{h}, 600 \mathrm{~L} / \mathrm{h}$, and 900 $\mathrm{L} / \mathrm{h}$ or $5 \mathrm{~L} / \mathrm{min}, 10 \mathrm{~L} / \mathrm{min}$ and $15 \mathrm{~L} / \mathrm{min}$ ) were tested with four $\mathrm{VAC}$ voltages and four VDC voltages to vary the results.

From Figure 2 (below), it can be seen that the higher the gas feed flow rate, the more ozone produced directly proportional to the amount of oxygen to be converted to ozone in the gas feed which also increases, so that ozone production increases with the flow of compressed air. rate of increase. The optimum compression air flow rate tested in this study is $900 \mathrm{~L} / \mathrm{h}$ or equal to $15 \mathrm{~L} / \mathrm{min}$. 


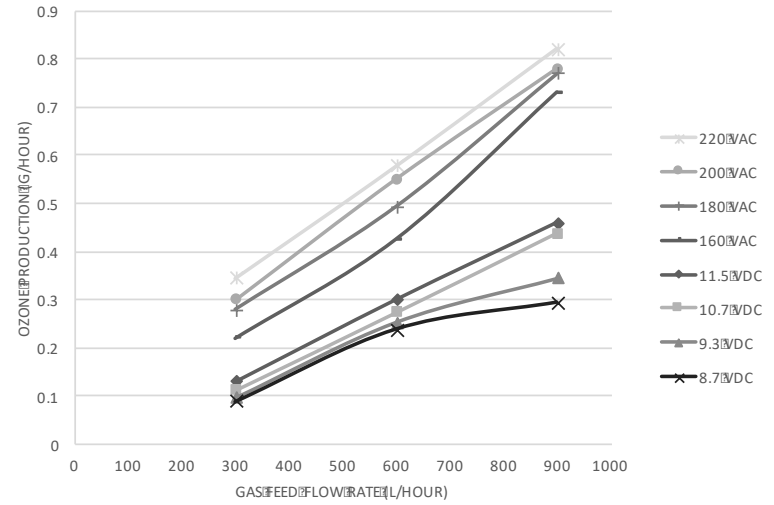

Fig. 2. The gas feed flow rate effect on ozone production

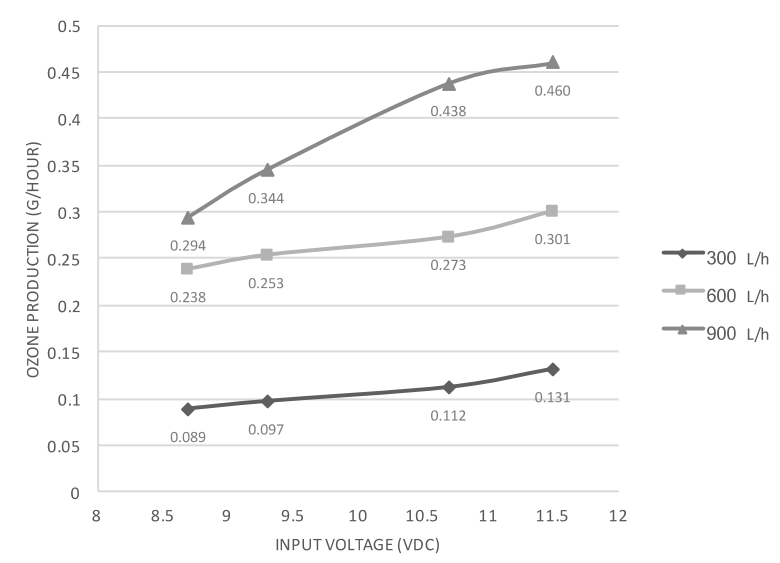

Fig. 3. The input voltage effect on ozone production in DC current parallel plate plasma reactor

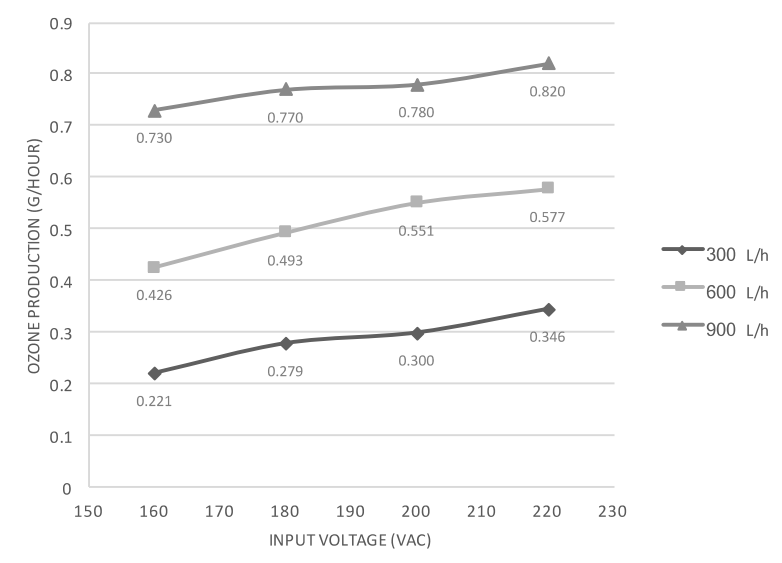

Fig. 4. The input voltage effect on ozone production in AC current parallel plate plasma reactor

\subsection{The effect of input voltage on ozone production}

The effect of input voltage on ozone production was tested with four variations of voltages in AC and DC current parallel plate plasma reactors, and three different compressed air flow rates.

It can be seen from Figure 3 and Figure 4 that with the increase of voltage, the ozonator productivity also increased. This was caused by a higher power used in higher input voltage that can accelerate the process of ozone formation in the parallel plate plasma reactor.
Also, the time required by ozone to react with the KI solution which is indicated by the color changes from clear solution to brownish yellow on the bubbler was even faster because of the higher ozone production. Therefore, more ozone produced within the increase of the input voltage.

Medical oxygen with $99 \%$ oxygen purity was also used as the gas feed to test the effect of input voltage on ozone production. Two different voltages and two different flow rates were applied. The result also supported the theory stated in the previous paragraph.

\subsection{The effect of gas feed type on ozone production}

Compressed air and medical oxygen were both tested as the gas feed of the parallel plate plasma reactor to study and compare the effect of gas feed type on ozone production at room temperature. The gas feed flow rate used was $900 \mathrm{~L} /$ hour or equal to $15 \mathrm{~L} / \mathrm{min}$.

Table 1. Ozone produced using $900 \mathrm{~L} / \mathrm{h}$ feed flow rate at 220 Volts (AC)

\begin{tabular}{|c|c|}
\hline Gas Feed & $\begin{array}{c}\text { Ozone } \\
\text { Production }(\mathbf{g} / \mathbf{h})\end{array}$ \\
\hline $\begin{array}{c}\text { Compressed } \\
\text { air }\end{array}$ & 0.820 \\
\hline $\begin{array}{c}\text { Medical } \\
\text { oxygen }\end{array}$ & 6.451 \\
\hline
\end{tabular}

Table 2. Ozone produced using $900 \mathrm{~L} / \mathrm{h}$ feed flow rate at 11.5 Volts (DC)

\begin{tabular}{|c|c|}
\hline Gas Feed & $\begin{array}{c}\text { Ozone } \\
\text { Production }(\mathbf{g} / \mathbf{h})\end{array}$ \\
\hline $\begin{array}{c}\text { Compressed } \\
\text { air }\end{array}$ & 0.460 \\
\hline $\begin{array}{c}\text { Medical } \\
\text { oxygen }\end{array}$ & 2.413 \\
\hline
\end{tabular}

As can be seen in Table 1 and Table 2 it was obtained that the use of medical oxygen as gas feed produced about six times higher amount of ozone than using compressed air. This is because the composition of oxygen in the air is only $21 \%$, much more smaller than nitrogen which is $78 \%$, while medical oxygen has $99 \%$ oxygen purity.

The presence of nitrogen and moisture in the air often leads to the occurrence of NOx compounds in discharges that can destroy the ozone that begins to form as it does in the Earth's stratosphere. Therefore, medical oxygen is the best gas feed to obtain very high ozone production but with much more production cost than compressed air.

When tested with $900 \mathrm{~L} / \mathrm{h}$ feed flow rate and medical oxygen as the gas feed, the parallel plate plasma reactor is capable of generating up to $5.103 \mathrm{~g}$ ozone/h at $220 \mathrm{~V}$, and $2.413 \mathrm{~g}$ ozone $/ \mathrm{h}$ at $11.5 \mathrm{~V}$. 


\section{Conclusion}

From the experimental results, by varying the parameters of gas feed flow rate, input voltage, and gas feed type for the process of ozone generation at room temperature using parallel plates plasma reactor, it can be concluded that the higher feed flow rate and input voltage used, the higher the ozone production. On the other hand, the use of medical oxygen as gas feed can produce almost eight times more ozone than compressed air, but certainly with higher production costs. However, it seems that the cost of maintaining the ozonator equipment still needs further research for both types of feed.

The optimum operating conditions with highest ozone production based on this study were at a voltage of 220 VAC, with $900 \mathrm{~L} / \mathrm{h}$ gas feed. The amount of ozone that can be produced using compressed air feed is up to 0.82 $\mathrm{g} / \mathrm{h}$, which exceeds the previous ozonator models that were designed and developed in the Department of Chemical Engineering, Universitas Indonesia.

Medical oxygen is the best type of feed gas for the plasma reactor to obtain the highest ozone production compared to compressed air. But if higher ozone production is not needed, compressed air is more economical.

This research was funded thanks to "PITTA Grant" (Hibah Publikasi Internasional Terindeks Tugas Akhir Mahasiswa Universitas Indonesia) 2018, organized by the Directorate of Research and Community Service (DRPM) - Universitas Indonesia. The authors state that there is no competing interest or any financial conflict of interest.

\section{References}

1. U. Von Gunten, Review ozonation of drinking water: Part I, Oxidation kinetics and product formation, Water Research, 37, 1443 - 1467. (2003)

2. C. Salomon, Ozone Disinfection. West Virginia: National Small House Clearinghouse, (1998)

3. R. G. Rice and A. Netzwer, Handbook of Ozone Technology and Applications. Ann Arbor Science Publisher, 1 (1982)

4. W. Smith, Principles of Ozone Generation, Watertec Engineering Pty Ltd., Australia, (2011)

5. W. von Siemens, Über die electrostatische Induktion und die Verzögerung des Stroms in Flaschendrähten, Poggendorff's Ann., 102, 120. (1857)

6. W. W. Eckenfelder, A. R. Bowers, J. A. Roth, Chemical Oxidation: Technology for the Nineties, 2 (1993)

7. N.N. Greenwood, A. Earnshaw, Chemistry of The Elements Second Edition, Butterworth-Heinemann, Linacre House, Jordan Hill, Great Britain, p. 609. (1998)

8. A. Lukmanto, Rancang Bangun Ozonator Koaksial Shell and Tube Untuk Pengolahan Air Bersih dan Air Minum. Depok: Department of Chemical Engineering, Universitas Indonesia, (2009)

9. A. Adami, Rancang Bangun dan Uji Kinerja Ozonator Koaksial Tipe Aliran Triple Pass untuk
Pengolahan Air. Depok: Department of Chemical Engineering, Universitas Indonesia, (2011)

10. Winanti, W.S., Purwanto, W.W., Bismo, S., Decomposition of Carbon Dioxide in the Three-pass Flow Dielectric Barrier Discharge Plasma Reactor. IJTech. 5(1), 51 (2014) 